\title{
日本の建築領域の産業特性に関する課題に関する一考察
}

\author{
建築コンポーネントの設計プロセスにおける技術的な知識の偏在
}

\section{STRUCTURAL PROBLEMS IN THE CONSTRUCTION INDUSTRY IN JAPAN}

Focusing on uneven distribution of technological knowledge in design process of components

$$
\text { 吉田 敏*1 }
$$

\section{Satoshi YOSHIDA}

\begin{abstract}
This paper discusses technological knowledge mobility in design process of architectural projects. The research focuses on design information for technological knowledge-based designs by architects and engineers. The research framework was based on the expression of technological knowledge and responsibility, because it is possible to understand that the characteristics of the design system depends on the allocation of drawing creations and final approval and responsibility. The purpose of this paper is to develop a method to explain the tendency of technological design process in architectural projects, and to understand structural problems in of the Japanese construction industry.
\end{abstract}

Keywords : technological knowledge, design process, knowledge mobility, design information, responsibilities of construction 技術的知識, 設計プロセス, 知識の移動, 設計情報, 施工責任

\section{1. はじめに}

現在、日本の建築産業で行われている設計行為は、多層化された プロセスによって構成されている。言い換えれば、建築の意匠設計 者、構造設計者、設備設計者に加え、建築に付帯される各部品や製 品の設計者らの複数の設計者によって、重層化した設計に関する情 報の作成を、慣行化された複雑なプロセスによって進められている 注 1)。要するに、複数の異分野の設計者によって、様々な技術領域が 部分的に重なりつつ、一つの建物のための設計情報を作成していく ということになる。

一方、契約面を見ていくと、建築プロジェクトでは、建築の発注 者と直接契約するのは、全ての設計者というわけでなく、主たる建 築設計者と建築施工者などに絞られる面があることは否めない。そ のため、建築発注者は主たる建築設計者に建築設計に関する情報作 成の全体を任せるという位置づけになる傾向があることになる。つ まり、発注者は、建築に関する全ての部品やシステムの品質や安全 性などについて、技術的な知識の有無は問わないまま、主たる建築 設計者に任せることになる。

ここ数年、国内において、社会全体が注目するような技術的な課 題や事故が散見されてきた。そして、その対応のための原因の究明 と、それに即した対応の必要性が高まってきたと考えられる注 2)。し かし、建築の技術領域においては、未だに根本的な処方箋が明示さ れたとは言い切れず、解明していかなければならない点が少なから
ず残ったままであると言わざるを得ない。

特に、設計行為の目的といえる設計情報の作成については、技術 的な課題や事故に起因する内容とつながる可能性が否定できない面 がある。設計情報を誰が作成しているのかという点に着目すると、 少なくともその作成者が対象についての知識を持っている中心的な 立場であることが考えられる注 3)。逆にいえば、十分な設計情報作成 に関する知識が無い限り、実際の設計を進めて設計図や仕様書にま とめることが難しいという面があるということである。

本稿の目的は、建築のコンポーネントの設計プロセスを精査し、 建築を構成する部品やシステムについて、誰が技術的知識を有し、 誰が品質や安全性についての契約上の責任者か等を、明確にしてい くことで、現状の課題を把握していくことである。そして、その課 題に対する処方箋に関する一つの考え方を明示していくことである。

\section{2. 設計プロセスと技術的知識}

\section{1 設計プロセスにおける技術的知識と組織間分業}

建築を含む、有形の製品を創る産業を対象として、設計プロセス と技術知識に関し、複数の先行研究や学術的理論が存在する。人工 的に創られるものは、一般的に、内的要素を外的環境に適合させる ことによって、必要な機能を実現させるという指摘がある注4)。この 指摘によると、設計者は、外的環境をよく理解した上で、内的要素 を求められる方向性に沿うように構成させていく必要があることに

\footnotetext{
"1 東京都立産業技術大学院大学 教授 ·博士 (工学) Prof., Advanced Institute of Industrial Technology, Dr.Eng.
} 
なる。つまり、対象の内部要素についての知識と、外的環境につい ての情報を、持ち合わせていることが必要となる。また、設計の主 要な流れとしては、概念設計、基本設計、生産設計を経て、設計解 を得るという過程となる注5)。これらの過程では、対象が製造され、 使われていくことに関し、必要な情報をつくり上げていくことが求 められる。このような過程を俯瞰すると、設計者は対象についての 外的環境と内部要素に関する情報と知識を十分に持っている必要が あることになる。

従来の企業間分業。組織間分業に関する議論では、分業システム の方向性に関し主導的な立場にとって必要な能力は、技術的な内容 を中心とした知識にあると考えられてきた。また、このようなシス テムの構築には、システムの構成要素間の関係に関する知識と情報 が重要であると考えられ、その知識は簡単に流出やコピーされるも のではないとされている6)。

知識の共有は、タスクに関する情報の授受として理解できるとさ れ、このような知識の共有には、新しいプロセスやアイデアを開発 するための他者との協働が含まれると考えられている7)。知識の共 有は、製品やサービスの開発に重要な影響を与えるが、問題や課題 の解決、他の立場を支援する意欲、他組織からの新スキルの獲得な どの行為等から生成すると考えられている ${ }^{8)}$ 。また、知識の共有は、 他の専門家とのコミュニケーションで得ることもできると考えられ ており、知識の客観化と文書化で開発することができるという指摘 もある 9)。

組織的能力と知識共有行動の関係の重要性については多くの議論 が存在する ${ }^{10)}$ 。一般的には、組織的能力は重要な知識を処理した結 果として成立すると考えられる ${ }^{11)}$ 。知識の共有が、組織的能力の基 盤となる可能性があることも議論されている 12)。知識共有の中でも、 知識の作成、伝達、および移動が、組織的能力を向上させる可能性 があると考えられている 13)。一方、知識の共有により、設計者とエ ンジニアは組織全体で組織的能力の向上を維持し、実践的な意思決 定のためのフローを開発するとされている ${ }^{14)}$

しかし、これらの先行研究では、自動車産業、電子機器産業、素 材産業、鉄鋼産業などが中心であったが、建築産業を対象としたも のは殆ど存在していない。そのために、これらの先行研究で指摘さ れている内容に注視しながらも、建築の独自性について抑えておく 必要がある。

建築では、内部要素、外部環境共に、必要とされる情報と知識が 極めて多いことが理解できる。これは、関与者の範囲、部品の点数、 技術分野の範囲などからみても、明らかであると考えられる。特に、 コンポーネントを中心とする内部要素については、様々な技術分野 に基づく多くの要素で構成されており、設計プロセスの中で、多く の産業分野や製品分野に関する技術的な知識が必要となる。例えば、 学術分野で分けて考えてみても、建築学分野以外の領域をべースと したものも多く存在し、電気、電子、情報、機械、物理、化学など の学術分野が使われることになる。製品領域や素材領域で考えてみ ても、空調設備、衛生設備、電気設備、構造部位、耐火等の機能素 材、外部仕上げ素材、内部仕上げ素材、セキュリティ等の運用シス テムなど、多くの領域が関わることになる。外部環境についても、 直接の使い手だけ注目しても複雑性が高いことが把握できる面があ る。使い手が特定少数である場合だけでなく、特定多数、不特定少
数である場合も十分に考えられ、不特定多数のケースも少ないとは 言い切れないと言える。その上、それらの使い手の範囲は、時間之 共に変化していくことも考えられる。そして、このような使い手の 要望を考えてみると、継時的にどのように変化していくのかについ ては、高い不確実性が内包されている面を否定しきることは難しく、 関連する外部環境の把握と対処に高い不確実性と複雑性が含まれる ことになると考えられることは否定できない。また、もちろん、そ の他の外的環境も、数十年という建築の使用期間を考えると、多く の環境が変化していくことが考えられ、対処に難しさが存在するこ とになる。

このように、多くの学術領域、製品領域の内部要素で構成され、 不確実性が高い外的環境を前提とする中、建築設計は進められるこ とになる。そのために、実際の建築の設計プロセスには、主たる建 築設計者だけでなく、多くの建築コンポーネントである製品やシス テムの設計者が加わることになる。例えば、空調設備の技術者、工 レベータの技術者、立体駐車場の技術者など、製品についての専門 知識が無いと設計行為が困難な分野では、いずれのプロジェクトで も建築設計プロセスに専門知識を持つ者が建築設計プロセスに参加 することになる。

\section{2 建築の設計プロセスにおける品質や安全性に関する責任}

日本の建築領域では、一つの典型的なケースとして、主たる建築 設計者が建築発注者と契約することが、唯一の設計に関する契約行 為であるというパターンを認識することができる。本稿では、この 契約というものを、主にプロジェクトの技術的な責任や役割を任せ る相手の明確化という考え方で捉えながら、議論を進めるものとす る。

もちろん、主たる設計者は、建築構造設計者、建築設備設計者、 製品およびコンポーネント設計者との間で分業しながら設計プロセ スを進めていく。このとき、特に重要であると考えられることの一 つに、設計作業の範囲と、品質や安全性に関する責任が、どのよう に分配されるかということである。

特に、誰がどのような設計作業の範囲を担っているのか、という 点については、このように複雑性が高い状況において、確認してい く重要性が高いと考えられる面がある。つまり、誰が基本的な考え 方をつくり、誰が実際の設計情報をつくり、誰が承認行為をしたの かについて、使われている技術領域が広いために、正確に理解する ことが重要になると考えられる。

一方、主たる設計者は、すべての建築部品、建築素材、導入製品、 導入システムについて、契約上の責任があり、それらの導入理由に ついては説明責任を担うことになる。ただし、主たる設計者は、導 入される多くのものについて、前述のように全ての知識や情報を持 っているとは考えられない面があるため、様々な技術者の知識に依 存しながら、必要な設計情報全体をまとめ上げていくことになる。 したがって、主要な設計者は、専門のエンジニアと協力して、製品 とシステムを導入する理由を明確にし、安全性と機能性に関する技 術的保証を提供する必要がある。

また、主たる施工者も、主たる設計者と同様に、建築発注者と契 約行為を取り交わすことになる。この施工者も、実際の施工図レベ ルの設計情報の作成を中心に、設計プロセスの一部を担うことにな 
る。しかし、主たる設計者と同様に、施工者も全ての技術的知識と 情報を持ち合わせているわけでなく、多くの技術者の知識に依存し ながら、設計情報をつくり、実際の建築を造っていくことになる。

問題は、建築発注者と契約するのは、主にこのような二者（主た る設計者と施工者）であり、設計プロセスに関与する多くの技術者 は、建築発注者と直接契約を結ぶことが無い点である。このような 状況により、建築発注者は、設計プロセスに参加する多くの技術者 について、プロジェクトに参加してもらっている認識すら無い場合 も考えられることになる。特に、一次下請、二次下請、三次下請な ぞの重層的な契約構造の中、誰が参加し、誰が実際の設計情報をつ くっているのかについて、認識できていない建築発注者が多いとい う可能性は否定しきれないと考えられる。

ここまでの考察により、建築プロジェクトの中で、設計情報を創 っていく立場が誰か、実際の技術的知識を持つ立場は誰か、技術的・ 品質的な責任を持つ立場は誰か、安全面の責任を持つ立場は誰かな どについて、明確化が成されていない場合、そして、つくり手全体 の組織的な構造として的確な構成が成されていない場合、根本的な 産業構造としての問題がある可能性が含まれることになる。特に、 設計の流れの重層化の観点から、建築を構成するコンポーネントに 注視していくものである。

\section{3 建築設計プロセスにおける技術的知識}

このような観点から、まず、誰が十分な技術的な知識を持ってい るのかについて、考察を進める。

技術的な知識を誰が持っているのか、どこにあるのかということ について、理解するのが困難な点は、推し量る尺度がないことであ る。技術者として対象について大体解っている人がいても、正確に 必要とされる部品やコンポーネントをつくることが難しい場合があ ることは容易に想像できるといえよう。そのため、本稿ではこれま での考察に即し、設計できるかどうか、という点に焦点を絞ってい きたい。

一つの部品やコンポーネントを取り上げたとき、複数の立場の技 術者たちが設計できる場合がある。このような場合、元請と言われ る組織の技術者が、協力企業と言われる組織の技術者に、設計作業 を依頼することが考えられる。この場合、協力企業の技術者によっ て作成された設計内容を、元請の技術者が確認して承認していくこ とになることが、一つの典型的な作業の流れである。しかし、ここ までの考察通り、主たる設計者が全ての部品やコンポーネントの技 術的知識を持ち合わせていない以上、設計を依頼する立場が十分な 技術的知識を持ち合わせていないケースが出てくることになる。建 築産業では、この点について、承認するだけの知識は、設計の発注 側が持っているということを前提とした慣行的なプロセスが張り巡 らされていると考えられる可能性がありそうである。

少なくとも、建築生産のシステム全体について、誰がどのような 認識を持っているかについては不明瞭の中、建築の規則では、建築 設計者がプロジェクト全体の唯一の設計側としての契約者であり、 この意味において全ての設計内容に責任を持つ立場となっている点 は、事実として認識できることである。

本稿では、理論的、客観的に、建築設計プロセスにおける各立場 の役割を整理し、そこに存在する課題を考えていく。

\section{3. 実業における設計分業 \\ 3.1 設計作業の分業の概念}

前章の考察から、現状の建築産業の課題の一つの面を抽出するた めに、実際の建築設計プロセスにおける設計情報の作成と承認、技 術的知識の所在、つくられた製品やコンポーネントの品質責任、安 全性責任などを理解していくことが重要となると考えることができ そうである。ただし、前述の通り、技術的な知識は重要だが、一般 的なツールや測定でそれを理解し、その所在を確認することは困難 であると考えられる。そのために、技術的な知識がなければ進める ことが出来ない設計情報の作成のプロセスを検討していく。特に、 図面や仕様をコンパイルするために技術的な知識が重要であると考 えられるが、技術的な専門知識と判断は、各形状と仕様を調整しな がら決定および説明するために不可欠である注 4)。特に注目すべき点 は、設計図や仕様書を実際に作成するには、このような技術的知識 が不可欠であるという点である。また、反対に、技術情報を理解し ておらず、内容に関する指示を受け、図面作成のみを担当する $\mathrm{CAD}$ オペレーターのような立場は、設計情報の作成対象者から除外され ることになる。

一方、開発された部品やコンポーネントについては、その発案に 即した権利も生じることになる。一度考えられた部品や工法・構法 が、広く転用できる場合も考えられる以上、特許申請、もしくはそ の位置づけに準じる開発内容の使用権なども、軽視すべき事項では ないことになる。

また、性能や安全面に関する責任についても、極めて重要な側面 を持つ。工事中、そして竣工後に、一度深刻な問題が生じた場合、 対象の部品やコンポーネントを設計した者は、法律的にも、倫理的 にも、責任を持つことになる。当該の立場であれば、工事中、そし て竣工後に、対象の設計情報を保持する必要性があることになるが、 実際の建築プロジェクトでも反映されている側面であると考えられ る。

このような視点から、実際の建築プロジェクトにおける設計プロ セスを精查し、眓面や仕様書の作成行為、その内容の承認行為を中 心に整理していく。このような考え方に基づくものとして、先行研 究に、自動車業界における複数の設計者の役割が分析されているも のがある ${ }^{15)}$ 。複数の設計者の役割分担中に、自動車のメイン設計者 と協力会社のサブ的な設計者に基づいて、役割をいくつかのパター ンに分割できることが指摘された内容である。この論文は、電子部 品、化学素材、飲料品、鉄鋼などの産業の研究に影響を与えたと考 えられ、複数の先行研究が行われている。本稿では、このような多 くの産業で議論が可能であった考え方を基盤とし、未だ試みられて いない建築分野で、試論を展開するものである。

この先行研究では、全体的な設計者と部分的な設計者の関係が、 自動車産業における設計の役割分担のために 4 つのパターンに分類 されている 15)。最初のパターンは、すべてを設計するメイン設計者 が全ての設計内容を決定し、図面と仕様書を作成し、図面と仕様を 協力会社側に貸すことによって生産のみを委託するものである。2 つ目は、対象のメイン設計者と協力会社のサブ設計者が設計の協力 をし、メイン設計者が設計ドキュメントと開発内容の使用権を所有 するパターンである。3 番目のパターンでは、対象のメイン設計者 とサブ設計者が設計の協力をし、サブ設計者が設計ドキュメントと 
Table 1 Classification of design activities in the automobile industry ${ }^{15}$

\begin{tabular}{|c|c|c|c|c|c|c|c|}
\hline & & & \multicolumn{3}{|l|}{ Design works } & \multicolumn{2}{|l|}{$\begin{array}{l}\text { Responsibilities } \\
\text { and authorities }\end{array}$} \\
\hline & & & Parts production & Detailed design & Basic design & $\begin{array}{l}\text { Right to own } \\
\text { drawings }\end{array}$ & Quality assurance \\
\hline \multicolumn{3}{|l|}{\begin{tabular}{|l} 
Self- \\
Manufacturing
\end{tabular}} & Car manufacturer & Car manufacturer & Car manufacturer & Car manufacturer & Car manufacturer \\
\hline \multirow[t]{4}{*}{$\begin{array}{l}\text { Manufacturing- } \\
\text { Outside }\end{array}$} & \multicolumn{2}{|l|}{$\begin{array}{l}\text { Lending drawing } \\
\text { method }\end{array}$} & Parts supplier & Car manufacturer & Car manufacturer & Car manufacturer & Car manufacturer \\
\hline & \multirow[t]{2}{*}{ Black box method } & $\begin{array}{l}\text { Contract drawing } \\
\text { method }\end{array}$ & Parts supplier & Parts supplier & Car manufacturer & Car manufacturer & Car manufacturer \\
\hline & & $\begin{array}{l}\text { Drawing approved } \\
\text { method }\end{array}$ & Parts supplier & Parts supplier & Car manufacturer & Parts supplier & Parts supplier \\
\hline & \multicolumn{2}{|l|}{ Commercial parts } & Parts supplier & Parts supplier & Parts supplier & Parts supplier & Parts supplier \\
\hline
\end{tabular}

開発内容の使用権を所有するパターンである。 4 つ目は、サブ設計 者が設計し、設計書や開発内容の使用権を保有し、メイン設計者が 内容を理解した上で設計内容を承認寸るというパターンである。ま た、これら以外に、市販品を購入寸る形での部品やパーツの導入と いう考え方が示されている。いずれの場合も、メイン設計者は最終 製品の品質、パフォーマンス、安全性などに責任があるが、設計が 完全に委任されたパーツについては、そのパーツを担当する会社の サブ設計者も責任を担う場合がある。この概念は、メイン設計者と サブ設計者の権利と責任が表裏一体であるという前提に基づいてい るものである 15)。この内容をまとめたのが、Table1 である。

この研究では、著者は設計作業と責任と権限を指標として注目し、 複数の設計者間の関係を分類しているわけである。内部製造の場合、 自動車メーカーのみが技術的な知識を持っている。また、商用部品 の場合は、部品サプライヤーのみが技術的な知識を持っているとい える。この研究で指摘されている日本の自動車産業の特徵は、複数 の設計者が対象部品を設計できる同程度の能力を持っているという ことである。たとえば、自動車メーカーの設計者と部品サプライヤ 一の技術者は、同じ部品を設計するための技術知識を持っている場 合があることが触れられている。違う点の指摘としては、これらの 設計者は、契約図面作成と図面承認方法に関してほぼ同じレベルの 知識を持っていることが議論されている。これは、これらの設計者 がお互いを刺激し、高いレベルの総合的な専門知識を維持できる可 能性を示唆し、さらに、最終製品は、この高い技術知識に基づく高 性能レベルを維持できる可能性があるとされている。

\section{2 建築設計における分業の類型化}

この項では、前項の先行研究の内容を参考にしながら、建築産業 における考察を進めていく。特に、建築設計プロセスの中で、誰が 基本的な設計情報を作成し、誰が生産に関する詳細情報を作成し、 誰が設情報を保存し、誰が建築設計内容の品質を維持する責任があ るかを検討していく。言い換えれば、自動車産業の産業特性と建築 産業の産業特性は様々な相違点があるため、全体を俯瞰するのでは なく、建築設計の担当者とコンポーネントの技術者の、設計行為に おける役割に、焦点を絞って考察を加えていく。

前述のように、建築はさまざまな技術領域と専門知識に基づく要 素で構成されているため、一部の要素には高度な専門知識が必要で ある。そのために、設計プロセスの管理が正確に行われていないと、
設計者やエンジニアが建築要素の作成能力だけでなく、評価能力を 維持できなくなる可能性がある。また、部品や材料の設計者が作成 した情報が、その技術的意味を理解されずに、要素の各ブロックの メイン設計者およびコンストラクターによって使用される可能性が ある。場合によっては、これらのギャップにより、構造や機構に明 らかな欠陥が生じることが㲘念されることになる。

先行研究 16)で指摘されている日本の自動車産業の特徽は、複数の 立場の設計者が同じ部品を設計できる能力を持っていることである。 たとえば、Table1 の内製（Self-Manufacturing）を除く枠組みの中 では、自動車メーカーの設計者と部品サプライヤーは、ある部品を 設計するための技術知識を持っている場合があると、事例を調査し たうえで指摘されている。この場合、複数の設計者が、つくるため の必要なレベルの技術知識は持っていると考えることができ、図面 作成と図面承認に関して、ほぼ同じレベルの技術知識を持っている ことを前提とすることができていると指摘されている。この内容に ついては、両方の立場にある設計者がお互いを刺激し、高いレベル の総合的な専門知識を維持できることも示唆されている。

この考え方に基づき、本研究は論理的に実業の枠組みを読夕解い て記述を行っていくものであり、製品間比較も視野に入れながら、 建築領域の設計プロセスを検討していく。特に、設計行為を分業す る上で、設計の元請側が十分な知識と共に設計内容を理解できない 状態で、設計の下請け側に設計行為を任せた場合、自動車産業にも 重なる部分がある現行の枠組みでは、設計の元請側による機能面、 品質面、安全面などの必要な理解に基づく確認がなされない可能性 が、生まれるためである。まず、先行研究を参照しながら、設計プ ロセスを、基本設計と詳細設計に分けて考察していくものとする。 先行研究の考え方を基にしながら、この二つのフェーズを建築設計 プロセスの中で整理すると、基本設計とする内容は、建築発注者が 基本的なプロジェクト内容を把握すること、工事金額の算出するこ と、法規に適合していることを明示することなどを対象とするフェ ーズとする。

また、詳細設計とは、この設計情報があれば実際の建築や部位を つくることが出来ることを対象とするフェーズとし、これ以外の目 的のためにつくられた設計情報は基本設計に含まれるとする。この ため、慣行的な基本設計図、建築確認申請図、見積図、契約図、施 工図などの概念ではなく、実質的な設計情報制作に基づく段階に分 けた概念となる。 
Table 2 Classification of design process in architectural industry (basic design and detail design)



この考え方では、基本設計と詳細設計において、必要とされる技 術的な知識の範囲が異なる可能性が生じるため、建築設計者とコン ポーネントの設計者の役割を、設計情報の作成と承認という行為か ら理解していく必要がある。Table2 に先行研究に対応する建築設計 のプロセスパターンを整理した。

Table2 の横軸の設計共有の内容は、設計プロセスで共有できる役 割と義務を表している。設計プロセスは、基本設計と詳細設計に

大別しているが、各プロセスにおいて、実際の設計情報の作成、 設計情報の承認を明示する内容となっている。このような整理に基 づき、5つのカテゴリー（ 1）～5））に分類される。これは、自動 車産業を対象とした Table1 の考え方を準用したものであるが、建 築産業では、詳細設計を、建築設計者でもコンポーネント設計者で もなく、ゼネコンの技術者が担当する類型（例えばプレキャストコ ンクリート版など）が存在することだけが Table2 における差異の 要因となっている。

ここで、契約行為との関係性を抑えておくと、建築発注者と契約 を取り交わ寸立場である主たる設計者の役割を抑え直しておく。建 築発注者は、主に契約した主たる設計者を中心に、コミュニケーシ ヨンを図りながら、プロジェクトを進めていくことになる。逆に言 えば、建築発注者は、プロジェクトに参加している多くの技術者と は、殆ど直接コミュニケーションを取ることが無い面があると言え よう。そのために、主たる設計者は、多くの設計上のコンテンツに ついての説明責任があるといえる。また、設計情報の内容について 最終的な責任がある場合、プロジェクト期間の中で設計情報が変更 される可能性がある限り、常に情報内容が把握できていなければな らないことになる。それから、承認行為を行う立場については、十 分な技術的な知識と情報を常に蓄えておかなければならないことに なる。しかし、自ら設計情報をつくらない期間が長くなった場合、 そのような知識と情報を失っている状態に陷っている可能性が考え られる。

Table2 の内容を確認していくと、1)では、建築設計者が、基本方 針に基づきながら、コンポーネント設計に関する図面や仕様書など に集約される設計情報を作成していく。2)では、建築設計者が基本 設計に関する設計情報を作成し、建築施工者が詳細設計の設計情報 を作成する。その内容を建築設計者が承認するパターンである。こ こまでは、建築発注者と契約を取り交わしている立場が、設計情報
に作成に関する内容を担当していることになる。3)では、建築設計 者が基本設計情報の作成と詳細設計の方針作成を担当し、各コンポ ーネントの技術者が詳細設計情報を作成するパターンである。この 詳細設計情報は、作成後、建築設計者によって承認についての判断 が成されることになる。4)では、建築設計者が基本設計に関する設 計情報の作成まで行うが、詳細設計については、コンポーネントの 技術者が方針の決定から設計情報の作成まで行う。この場合、建築 設計者は部位の使用や要求性能までは決定することになる場合が多 いと考えられるが、技術的な知識の必要性に関する重心は、コンポ 一ネントの設計者に偏ることが考えられることになる。5)では、建 築設計者は、コンポーネント設計に関しては基本的な方向性を決定 するが、基本設計情報の作成、詳細設計の方向性、詳細設計情報の 作成は、部位の設計者が担当する。4)と 5)の場合、基本的な要求性 能や機能を建築設計者が決定するが、技術的な知識や情報が重要と なる詳細設計の実質的なつくり込みは、コンポーネントの設計者に 任されることになる。この場合、各プロジェクトを通して、建築設 計者に技術的な知識や情報が蓄積される傾向が薄い可能性があるこ とになる。つまり、コンポーネントの設計者には、情報と知識が蓄 積されていく傾向がある可能性、建築設計者には情報と知識が蓄積 されにくい可能性が含まれていることになる。

\section{3 設計プロセスの中の役割と品質責任との関係性}

Table3 は、Table2 の 1)〜5)の各パターンに対応させながら、コ ンポーネントの詳細設計と製作、契約関係、責任、権利に関する視 点から内容をまとめたものである。

前述の通り、国内の典型的なプロジェクトの一つのパターンとし て、建築発注者との契約を結ぶのは、主たる建築設計者と建築施工 者の二者が中心となる傾向がある。つまり、法的な詳細を述べるに は至らないものの、現行の商習慣では、建築発注者が直接契約を取 り交わす相手は、建築事業に参加する全関与者の極一部ということ になる。言い換えれば、協力会社と言われる様々なコンポーネント を扱う立場は、設計者としても施工者としても、建築発注者と直接 契約することが多いということは無いということになる。そのため 設計プロセスの中で、建築発注者は多くの様々なコンポーネントの 設計者を認識することが難しいと考えられる。しかし、建築設計者 と建築施工者が、全てのコンポーネントの安全性や品質に関する保 
Table 3 Classification of design process in architectural industry (basic design and detail design)

\begin{tabular}{|c|c|c|c|c|c|c|c|}
\hline \multicolumn{4}{|c|}{ Design works } & \multirow{2}{*}{\multicolumn{4}{|c|}{ Responsibilities and authorities }} \\
\hline & \multicolumn{3}{|l|}{ Detailed design } & & & & \\
\hline & $\begin{array}{l}\text { Concept design } \\
\text { Creating a design } \\
\text { direction }\end{array}$ & $\begin{array}{l}\text { Design information } \\
\text { Creating drawings and } \\
\text { specifications }\end{array}$ & Approval & Design Contractor & $\begin{array}{l}\text { Parts quality } \\
\text { assurance }\end{array}$ & $\begin{array}{l}\text { Right to own } \\
\text { drawings }\end{array}$ & Parts production \\
\hline 1) & Main architect & Main architect & - & Main architect & Main architect & Main architect & Sub-contractor \\
\hline 2) & General contractor & General contractor & Main architect & Main architect & Main architect & General contractor & Sub-contractor \\
\hline 3)-1 & Main architect & Sub-contractor & Main architect & Main architect & Main architect & Sub-contractor & Sub-contractor \\
\hline 3) -2 & Main architect & Sub-contractor & Main architect & Main architect & Sub-contractor & Sub-contractor & Sub-contractor \\
\hline 4) & Sub-contractor & Sub-contractor & Main architect & Main architect & Sub-contractor & Sub-contractor & Sub-contractor \\
\hline 5) & Sub-contractor & Sub-contractor & Main architect & Main architect & Sub-contractor & Sub-contractor & Sub-contractor \\
\hline
\end{tabular}

証や責任を担うことは、ここまでの内容のために、難しいと言わざ るを得ない。むしろ、詳細設計がコンポーネントの設計者中心に行 われる場合、技術的知識がコンポーネントの設計者に偏在する可能 性が否定出来ない。また、各部位の品質や安全性に責任を持つ場合、 その対象の情報を保持する必要性が生じることになる。つまり、多 層化された設計プロセスの中で設計された内容に対して技術的責任 を持つ意識がある以上、少なくとも対象の設計図や仕様書を、竣工 後も保存しておくことが基本となる。

Table3 の 1)では、設計者は建築発注者と契約行為を行う主たる 建築設計者が中心となり、設計内容に関する責任と権利の所在は明 確な傾向があると言える。この内容に従って、協力会社が対象の部 位の製作を行う。2)は、1) と基本的に近い内容だが、設計図書や仕 様書などの設計情報を建築施工者が保存することになるカテゴリー である。そのために、設計品質責任などについて、名目上は建築設 計者が担うが、実質的には建築施工者が担うために設計情報を保存 している可能性を含むものといえる。3)は、二つのタイプに分けて 理解すべき点がある。3)は、詳細設計に際し、建築設計者が方向性 を定め、コンポーネントの設計者が詳細設計を行い、建築設計者が 判断し承認するものである。Table3 で 3)-1 としているのが、対象 コンポーネントの設計上の品質保証を建築設計者が担うものであり、 3)-2 は、品質保証をコンポーネントの設計者が担うものである。た だし、両方のタイプ共に設計情報は協力会社側が保存することにな り、何らかの問題が生じたときには両社で議論する可能性が含まれ ることになる。4)と 5)は、Table3 の範囲は同じ内容となっている。 5)では、基本設計の設計情報作成も建築設計者が行わず、コンポー ネントの設計者が基本設計・詳細設計の設計情報の作成を行うこと になるが、この点だけが 4)と 5)の違いとなる。これらのパターンで は、建築発注者と契約関係にある建築設計者は、詳細設計の方針か ら作成まで関与することが無く、基本設計段階での確認だけを設計 者としての拠り所とすることになる。また、コンポーネントの設計 者は、建築設計者が関与した基本設計の内容に適応する範囲では、 どのような設計情報を作成してもよいという位置づけとなり、実質 的な詳細設計の決定者となる面があると考えられる。この場合、部 位によっては、基本設計で仕様のみを決定することも考えられるた め、対象の品質や安全性については、建築設計者が認識できていな い可能性も含まれることになる。
Table 4 The types of component to Table2 and Table3

1) Plaster Work, Painting Work, and Interior Finishing (Carpet, PVC, etc.)
2) Concrete Skeleton Construction, Reinforcement Placing,
and a Cast-in-place Concrete Pile
3)-1 Steel Structure, Precast Concrete Construction
3)-2 Stone Finishing Work, Aluminium Joinery Work, Steel Joinery Work
4) Precast Concrete Pile, ALC (Autoclaved Light-weight Concrete)
GRC (Glass Fibre Reinforced Cement), and Free Access Floor
5) Unit Bath, Lift, Air Conditioning Equipment, and Automatic Door

Table4 は、Table2 および Table3 に対応する代表的なコンポーネ ントをまとめたものである。基本的に、設計分業が伴うことを前提 に、元請が契約する対象企業の業種別に類型化した内容となってい る。これは、対象部位（部品、素材、コンポーネント等）に関する 設計、

生産、施工などが、分業の実質的な中心に置かれる面から、試行的 に取り上げる考え方に基づいている。この分類については、5 名の 国内の総合建設会社での 10 年以上の工事管理経験がある方々に協 力して頂き、標準的な事務所ビル工事を想定しながら各工種を分類 して頂き、全員の分類案を再度検討して頂き、主観の差異を抑える ために、デルファイ法の考え方を使いながら、内容の普遍性を優先 する形ではなく、参考としての一つの類型化にまとめたものである。

\section{4 技術的知識の偏在と課題}

ここまでの考察で、技術的知識の重要性と所在の理解を進めてき たが、いくつかの仮説を立てることが出来る。そのうちの一つとし て、詳細設計がコンポーネントの設計者中心に行われる場合、技術 的知識がコンポーネントの設計者に偏在する可能性が否定出来ない という仮説を考えることができる。本項では、この仮説について考 察を加える。

この仮説について、具体的に表すとすれば、技術的知識の偏在と いう観点からは、建築設計者に技術的知識が久乏する可能性が内包 する4)と5)のパターンを注視することが考えられる。このような知 識の偏在が起これば、建築設計者が品質や安全性について理解でき ていないまま設計情報がまとまっていく可能性が生じるということ 
である。結果として、承認行為についても、技術的知識が十分で持 ち合わせない中で行われ、実質的な意味が薄らぐ可能性があるとい うことになる。

Table1 の内容をまとめた自動車産業を対象とした先行研究の中 では、主たる設計者が協力会社の設計者に「まとめて任せる」とい うことが日本の自動車メーカーの強みの一つであるという主張がな されている ${ }^{16)}$ この場合、建築産業でも、当然そのような可能性を 含んでいると考えられる。建築設計者とコンポーネントの設計者の 両者が十分な技術的知識を持ち、コンポーネントの設計者にまとめ て任せることによって高いレベルの設計情報が創られ、その重要性 や課題を建築設計者が確実に理解しながら設計プロセスを進めてい くことになる。ただし、自動車産業で指摘されている強みに関する パターンは、Table2 と Table3 では、3)のパターンに当たり、4)と 5)の検討は異なる意味が生じることになる。ただし、ここでは多角 的な分析が必要な競争力や開発力の議論までは取り上げず、この点 は他稿に譲るものとする。本項では、技術知識の所在についての課 題に焦点を絞るため、設計情報の課題が直接的かつ集約的に表出す る、コンポーネントの安全性の確保について考察を加えていくもの とする。

古阪らによると、「日本の建築生産システムでは、法規範や准規範 の曖昧さを各主体の ‘善意のアプローチ’によって互いに補完する ことによって高い品質が確保されてきたが、経済情勢等によって各 主体が“善意のアプローチ’を行わなくなれば品質事故につながる」 としている 1)。ここでは、このような本質的な視点に加える形で、 設計情報の作成から把握し得る技術的知識の偏在に焦点を絞ること にする。そのために、具体的な代表的事例をあげ考察を加えること と、複数の事例をあげて傾向を確認することの両面について、検討 を加えていくものとする。

国土交通省は、『建築物等における事故・災害対策』の中で、『建 築物等における事故対策について』に、独立した形で $2 つ$ 事故が 取り上げられ、対応されている。「エレベータ」と「自動回転ドア」 である注 9)。また、平成 27 年に、独立した委員会「基礎ぐい工事問 題に関する対策委員会」を設置し、特別な形で大臣告知とガイドラ インが策定された注 8)。ここでは、このような国土交通省によって特

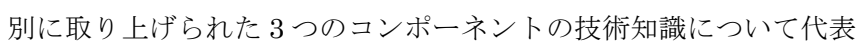
的な事例として考察を加える。また、個々のケーススタディだけで なく、全体の傾向も確認するため、ここ数年間の代表的な設計情報 に関する技術的知識の偏在と考えられる事故の類型を考察する。こ れらは、限定的な議論となる面はあるものの、本稿において焦点を 定めた技術知識の偏在の傾向についての仮説を、実業レベルで議論 できると考えられる。

\subsection{1 エレベータ}

昇降機については、国土交通省として、かなり恒常的に様々な要 件に対して対応してきていると言える。その中で、代表的なものの 一つが、2006 年に起こったシンドラー社の事故と考えられる。これ は、エレベータが開扉状態で上昇し、利用していた高校生が、エレ ベータの床面と開口部の枠に挟まれ、死亡したものである。エレベ ータの保守点検を担当していたエス・イー・シーエレベーター社が、 点検の際にブレーキ部の異常を見落としたことが直接的な要因とさ れているが、メーカー側の技術情報の隠蔽、それによる技術情報不
足も、要因として挙げられている注6)。これは、エレベータ本体の利 益率が小さく、メンテナンスの利益率が大きいという、エレベータ 産業の慣行的ビジネスモデルが、潜在的な要因であるとされている 注 5)。要するに、エレベータ本体をつくった企業がメンテナンスも請 け負うことが重要であり、このことによって各企業が長期に利益を 上げていくモデルとなっていたと言えそうである ${ }^{17) 。 ~}$

エレベータは、Table3 の 5)に当たるコンポーネントであり、建築 設計者はエレベータの主要な仕様などを決めるが、殆どエレベータ についての技術的知識は持ち合わせていないといえる。特に、エレ ベータが設置されるための空間と、電気の供給などは、エレベータ 側から要請が慣行化されており、当初の機器の機構的な技術的知識 について、殆ど建築側は持ち合わせていない状況と考えられそうで ある。また、業界の暗黙の了解のような、メーカーがメンテナンス も担当するという取り決めのような傾向があり、それに反する場合、 メンテナンスに必要な技術情報もメーカーから供給されなくなるこ とになる 17)。まさに技術的知識の偏在が明確に理解できると考えら れる。

\section{4.2 自動回転ドア}

2004 年 3 月に、六本木ヒルズの森タワーの正面玄関で、6 歳の男 児が三和タジマ製の大型自動回転ドアの回転ドア太ドア朹に頭部を 挟まれ死亡した。原因として、回転ドアの回転部の重量が重すぎた こと、危険防止センサーに死角があったこと、安全制御システムへ の過信があったこと、安全管理体制が甘くなっていたことの四点を 中心に理解されている。この事故を受け、国土交通省と経済産業省 によって、自動回転ドアに関する事故防止のガイドラインがつくら れた注 6)。

設計プロセスの問題は、本質的なものと言える面がある。当初、 オランダの企業によって回転部の重量が約 $0.9 \mathrm{t}$ だったものが、見栄 えと耐風圧などの要望から最終的に約 $2.7 \mathrm{t}$ となっていた。これは、 欧州の温度差に耐えることに特化した原形から、高層ビルの正面入 り口であるために見栄えと耐風圧が求められることになり、異なる 機能が計画されることになったことを表している。そのような中、 プロジェクトの途中で、オランダの企業が潰れるという状況が重な っている注 7)。

自動回転ドアは、Table3 の 5)に当たる部位である。建築設計者 は、自動回転ドアについて技術的知識を殆ど持ち合わせていない面 がある。そのために、建築設計者による独自の機能設計がなされ、 その機能設計に合わせたかたちで、コンポーネントの設計者による 自動回転ドアの設計がなされた。この場合、建築設計者は、国内の コンポーネントの設計者が、自動回転ドアの技術的知識を十分に持 っていなかった可能性をも理解できておらず、品質と安全性に関す る確信を持っている設計者がいなかったことを表しており、建築設 計者に技術的知識が無かったということを明確に把握することが出 来る。

\section{4.3 基礎杭}

2007 年竣工の横浜市のマンションで、 2014 年に 2 棟の建物のジ ヨイント部で $2 \mathrm{~cm}$ の段差が生じていることが発見され、2015 年に 国土交通省で委員会が立ち上げられた。取りまとめられた報告書の 中で、実際に支持層に杭が届いていないことの意味合いと、その原 因として、重層下請け化した施工体制、施工の不健全な慣行化、デ 
ータの流用の業界浸透などが指摘されている。委員会では、安全 への取り組み体制の確立、業界の風潮と個人の意識の刷新、責任体 制の整備、設計と施工の物件に即したルールの確立、高度技術・先 端技術の利用の、五点の論点と、再発防止策として、適正な設計・ 施工及び施工管理のための体制構築と、建設業の構造的な課題に関 する対策がまとめられた注 8 )。

まとめられた再発防止策の内容に即する形で、技術的知識の偏在 に関する議論がなされる面がある。基礎既成杭は 4)のパターンであ り、建築設計者および建築施工者に技術的知識が希薄になっていた としても、設計プロセスや施工プロセスが進められていく可能性が ある面がある。特に、協力会社が 3 次下請けまで重層化しており、 実際に技術的知識を持っている範囲がどの範囲なのかが、極めて重 要な点である。なぜなら、実際に設計と施工の十分な技術的知識を 持たない立場が複数重なった構造の場合、本稿での議論の指摘内容 が複雑化し、問題の明確化について、個々の案件を注意深く行わな ければならない面を否定することが難しくなるからである。

\section{4.4 技術的な課題による事故の類型}

また、個別のケーススタディに加え、様々な事故等の傾向を検討 してみる。国土交通省の会資本整備審議会の建築物等事故・災害対 策部会において、建築に関する事故や安全性の課題が議論されてき た。この中で、直近である令和 2 年 7 月 14 日の部会の中で、『特定 行政庁より報告を受けた建築物事故の概要』という資料が示されて いる注 10$) 。 内$ 容は、平成 27 年 11 月から令和 2 年 3 月の建築に関連 する事故等がまとめられているものとなっている。この中で、労働 災害事故、経年劣化、人為的ミス等ではなく、竣工後に起こった建 築の一般的な使用下で原因部位の特定ができる技術的知識の偏在に 起因する可能性がある事故を抽出する。また、それぞれの対象とな っているコンポーネントについて、Table 2 と Table 3 で該当するパ ターンを整理していくと下記のようになる。類型化の手法は、前述 の内容と同様にデルファイ法を活用したものとなっている注 9)。

・防火シャッター 4)

・ステンレス製フェンス 5)

・外壁面袖看板 3)-2

・吊り天井 4)

・天井ボード 4)

・天井パネル金属製看板 4)

・シャッターボックス 5)

・アルミ製手すり 4)

また、失敗学会のデータベースを参照すると、前項と同様の考え 方で抽出すると、以下のようなコンポーネントの問題となる注 6)。

・鉄骨主要構造部 3)-1

・基礎部 4)

・鉄骨製デッキ 3)-1

・昇降機 5)

・シャッター 3)-2

ここに、13 の工種が取り上げらえているが、4)と 5)が、併せて 9 つのコンポーネントとなっている。ここで指摘した 4)と5)について、 設計の元請の技術知識不足が必ず生じるということは言い切れない が、課題が含まれていることは理解できる。つまり、これらの現行 の枠組みは、設計の元請が、技術的知識を十分に持っていることが
前提になっている面があり、品質や安全性に関して責任を取る必要 があるが、それには技術知識範囲が広すぎるために問題点が含まれ ている可能性が高いということである。

ここまでにあげた内容は、中央行政庁の判断から専門の学術分野 の考察に至るまで、同一の方向性を示しているものであり、本項に おける、詳細設計がコンポーネントの設計者中心に行われる場合、 技術的知識がコンポーネントの設計者に偏在する可能性が否定出来 ないという仮説に矛盾は生じていないと考えられる。ただし、自動 回転ドアの事故などについて、法律面や倫理面からの議論は、異な る視点からこれらの事故の問題点を指摘することにつながるが、各 事故に関する総括的な議論は他稿に譲るものとする。慎重な議論が 必要であることは間違いと考えられるが、本稿では、技術的知識の 所在と、設計情報の流れから、課題を明確にしていくことに焦点を 絞るものである。

\section{4. まとめ}

本稿の目的は、建築の設計プロセスを精査し、建築を構成する部 品やシステムについて、技術的知識の所在を理解することによって、 現状の課題を把握していくことであり、その課題に対する処方箋に 関する一つの考え方を示していくことであった。特に、詳細設計が コンポーネントの設計者中心に行われる場合、現行の建築プロジェ クトのフレームワークの中では、技術的知識がコンポーネントの設 計者に偏在する可能性が否定出来ないという仮説を立てた。そして、 その可能性についての仮説に対して、矛盾が生じていない傾向を、 代表的な事例の理論的ケーススタディと、ランダムサンプリングさ れた直近の課題を含む事例の傾向を確認し、基本的に把握すること が出来たと考えられる。また、ケーススタディの中で、国土交通省 をはじめ、専門学術領域からも、様々な課題解決のための提案が示 されているが、本稿が理論的に導いた技術的知識の偏在に関する提 案は極めて薄めであり、本稿の考え方が処方箋としての一つの明確 な位置づけになると考えられる。

ただし、注意すべき設計分業パターンが示すことができても、そ れぞれの製品領域特性や素材領域特性によって、さらに深い分析や 考察が必要な場合があると考えられる。これは、各特性が、設計分 業パターンの影響だけでなく、他の多くの因子によって確立される ものであり、領域の慣行などの他の影響も少なからず影響を及ぼす ことによって、各領域の課題が生まれてくることは否定できない。 ただ、今回の設計分業パターンが重要な因子になることが否定され ることではなく、この視点を基軸に置きながら、様々な因子も議論 していくことが肝要であると考えられるものである。

また、本稿を通して考えられることは、現行の建築プロジェクト のフレームワークに課題が残る点である。主たる建築設計者がす心゙ ての技術知識を体得し、コントロールすることは、建築に関する技 術知識領域が広いために、困難であると考えられる。しかし、本稿 の主張としては、現行の技術知識の所在や設計情報生成の流れなど のフレームワークを精査すると、主たる建築設計者が様々な責任を 集中的に担う必要がある面が否めず、そこに課題が見えてくるとい うことである。言い換えれば、誰が技術的知識を持ち、誰が技術的 な責任を持ってプロジェクトに臨み、どのように安全性や品質など を実現していくのか、注意深く検討していかなければならない必要 
性の概要が理解できたと考えている。今後、建築設計に関する枠組 みの慎重な検討と、主な製品や素材を中心に、一つ一つの建築に含 まれるコンポーネントについて、その特性を精査しながら、あるべ き技術的な分業に関する議論を、進めていくことが重要であると考 えられる。

また、自動車産業の先行研究の示唆より、主設計者と協力企業の 設計者が技術的知識を保持し合う状況であれば、まとめて任せるこ とによって、高い品質や安全性が創出される可能性が考えられる。 この点については、今後、検証し、日本の建築産業の強みを描いて いく可能性を追うことも重要であると考えられる。

\section{参考文献}

1) Furusaka. S. : Kenchikuseisan, Rikoutosyo, 2009 古阪秀三編著：建築生産，理工図書，2009

2) Takamura Y. : Shippaigakunosusume, Kodansha, 2005 畑村洋太郎：失敗学のすすめ, 講談社, 2005

3) Fujimoto, T. : Nihonnnomonodukuritetsugaku, Nikkei.co., 2004 藤本隆宏：日本のもの造り哲学，日本経済新聞社，2004

4) Herbert A. Simon: The Science of the Artificial, MIT Press, Cambridge, MA, 1969

5) Yoshikawa, H., and Tomiyama, T. : Sekkeigaku -Monodukurino riron-, Housou Daigaku Kyouikushinkoukai, 2000

吉川弘之, 富山哲男：設計学 —ものづくりの理論一, 放送大学教育振 興会, 2000

6) Brusoni, S. \& Prencipe, A. : Managing knowledge in loosely coupled networks: Exploring the links between product and knowledge dynamics. Journal of Management Studies, 38(7), pp.10191035. 2001

7) Park, S., and Kim, E. : Revisiting knowledge sharing from the organizational change perspective, European Journal of Training and Development, Vol. 39 No. 9, pp. 769-797.2015

8 ) Davenport, T.H., and Prusak, L. : Working Knowledge: How Organizations Manage What They Know, Harvard Business School Press, Boston, MA 2000

9) Sousa, M. J., Cascais, T. and Rodrigues J. P. : Action research study on individual knowledge use in organizational innovation processes, in Rocha, A., Correia, A.M., Costanzo, S. and Reis, L.P. (Eds), New Contributions in Information Systems and Technologies, Spring Nature, Berlin, pp. 75-82.2015

10) Swift, P.E. and Hwang, A. : The impact of affective and cognitive trust on knowledge sharing and organizational learning, The Learning Organization, Vol. 20 No. 1, pp. 20-37 2013

11) Swart, J. and Kinnie, N. : Organizational learning, knowledge assets and HR practices in professional service firms, Human Resource Management Journal, Vol. 20 No. 1, pp. 64-78.2010

12) Kumaraswamy, K.S.N. and Chitale, C.M. : Collaborative knowledge sharing strategy to enhance organizational learning, Journal of Management Development, Vol. 31 No. 3, pp. 308-322. 2012

13) Lee, S., Kim, B. G. and Kim, H. : An integrated view of knowledge management for performance, Journal of Knowledge Management, Vol. 16 No. 2, pp. 183-203. 2012

14) Yang, J. T. : The impact of knowledge sharing on organizational learning and effectiveness, Journal of Knowledge Management, Vol. 11 No. 2, pp. 83-90. 2007

15) Fujimoto, T., Takeishi, A. and Aoshima Y. (Eds), Business Architecture, Yuhikaku, 2001

藤本隆宏, 武石彰, 青島矢一 編著: ビジネス・アーキテクチャ一製 品・組織・プロセスの戦略的設計, 有斐閣, 2001

16) Clark, K. and Fujimoto, T. : Product Development Performance: Strategy, Organization, and. Management in the World Auto Industry. Boston: Harvard Business School Press. 1991

17) Higuchi H.: Sidlar shasei elevator shiboujikono jireikenkyuu, Nihon Keiei Rinrigakkaishi, No.24, pp179-197, 2017

樋口晴彦：シンドラー社製エレベーター死亡事故の事例研究, 日本経 営倫理学会誌, 第 24 号, pp179-197, 2017

注

注1）参考文献 1)，第 6 章

注2）参考文献 2) ,

注3）参考文献 3)，第 4 章

注4）参考文献 4)，（日本版）pp6-16

注5）公正取引委員会事務総局『マンションの管理・保守をめぐる競争の実 態に関する調查』2003 発行

注6）失敗学会、『失敗知識データベース』 http://www.shippai.org/fkd/index.php（2020.08. 14. 閲覧確認）

注7）国土交通省、『自動回転ドアの事故防止対策に関する検討会』 https://www.mlit.go.jp/jutakukentiku/build/revolving_door.html (2020. 08. 14. 閲覧確認)

注8）国土交通省、『基礎ぐい工事問題に関する対策委員会中間とりまとめ 報告書』 https://www.mlit.go.jp/common/001114887.pdf (2020.08. 14. 閲覧確認)

注9）国土交通省、『建築物等における事故・災害対策』 https://www.mlit.go.jp/jutakukentiku/build/jutakukentiku_house_t k_000037.html（2020.08.14. 閲覧確認）。

注10） https://www.mlit.go.jp/common/001188843.pdf\#search='\%E7\%89\% B9\%Е5\%AE\%9A\%Е8\%A1\%8C \%E6\%94\%BF\%Е5\%BA\%81\%Е3\%82 \%88\%Е3\%82\%8A\%Е5\%A0\%B1\%E5\%91\%8A\%E3\%82\%92\%E5\%8F \%97\%Е3\%81\%91\%Е3\%81\%9F\%E5\%BB\%BA\%E7\%AF\%89\%E7\%89 \%A9\%E4\%BA\%8B\%E6\%95\%85\%E3\%81\%AE\%E6\%A6\%82\%E8\%A 6\%81'（2020.08. 14. 閲覧確認) 


\title{
STRUCTURAL PROBLEMS IN THE CONSTRUCTION INDUSTRY IN JAPAN
}

Focusing on uneven distribution of technological knowledge in design process of components

\author{
Satoshi YOSHIDA*1 \\ ${ }^{1}$ Prof., Advanced Institute of Industrial Technology, Dr.Eng.
}

This paper focuses on the location of technical knowledge and discusses the key points in the design process. To this end, we developed a description method that makes it possible to locate technical knowledge. We have also discussed the essential points that need to be understood for the development of the construction industry.

First, the perspectives provided in this paper are based on clarifying the location of technical knowledge and responsibility. As a result of varying backgrounds and business customs, what should have been a simple relationship started to include unnatural bias. From this, we can indicate the implications of the problems related to quality assurance of the design contents. Indeed, it is difficult for the main architect to take responsibility for the work that requires extensive knowledge of architectural design. However, it is necessary to clarify who has technical knowledge and who is responsible for the design.

Second, the location of technical knowledge changes. Technical knowledge will gradually change over time. Moreover, the layering of the design division of labor makes it difficult to indicate who will create the design information and who will approve it responsibly with its content. If the content and characteristics of knowledge and the relationships between the designers change, it is necessary to pay close attention to the uneven distribution of technical knowledge. It is necessary to add the considerations obtained from the previous chapter while describing the uneven distribution of technical knowledge, focusing on the types of construction that have caused serious problems and resulted in the recent accidents.

Thus, the points which could not be clarified in the discussions that did not focus on technical knowledge, may now be clearly recognized. Hence, we will continue to apply this description method to each construction, giving priority to constructions that affect safety, and add investigation and analysis.

Construction is a made-to-order production and it contains project-wise characteristics. In the future, the concept of this paper can be used while examining the important parameters of each project, such as complexity, uncertainty, and novelty. 